\title{
Protective Effects of Garlic Oil against Liver Damage Induced by Combined Administration of Ethanol and Carbon Tetrachloride in Rats
}

\author{
Ashraf B. Abdel-Naim a , Amani E. Khalifa ${ }^{a}$, Sherif H. Ahmed ${ }^{\text {b }}$ \\ a Department of Pharmacology and Toxicology, Faculty of Pharmacy, \\ Ain Shams University, Cairo, Egypt. \\ ${ }^{\mathrm{b}}$ Department of Biochemistry, Faculty of Agriculture, \\ Cairo University, Cairo, Egypt.
}

\begin{abstract}
Herbs are known to play a vital role in the management of various liver diseases. Garlic oil (GO) contains numerous organosulfur compounds with potential hepatoprotective effects. The present work was planned to evaluate the possible preventive role of GO on biochemical and histopathological alterations induced by combined administration of ethanol $(\mathrm{EOH})$ and carbon tetrachloride $\left(\mathrm{CCl}_{4}\right)$ in rat liver. Two dose levels of $\mathrm{GO}(5$ or $10 \mathrm{mg} / \mathrm{kg} / \mathrm{day})$ were administered orally to rats for 7 consecutive days with $\mathrm{EOH}+\mathrm{CCl}_{4}$-induced liver damage. Activity of GO against liver damage was compared with that of silymarin $(25 \mathrm{mg} / \mathrm{kg} /$ day, p.o. for 7 consecutive days). Biochemical parameters including serum aspartate aminotransferase (AST), alanine aminotransferase (ALT), gamma glutamyl transpeptidase $(\gamma-\mathrm{GT})$, alkaline phophatase (ALP) and bilirubin were estimated to assess the liver function. In addition, the level of total proteins, triglycerides, total cholesterol, glutathione (GSH), and thiobarbituric acid reactive substances (TBARS), in liver tissues were estimated. Liver damage was evidenced by an increase in the activity/level of AST, ALT, $\gamma$-GT, ALP and bilirubin in sera of rats after the combined administration of $\mathrm{EOH}$ and $\mathrm{CCl}_{4}$ compared to normal animals. Pretreatment of rats with $\mathrm{GO}$ reduced the $\mathrm{EOH}+\mathrm{CCl}_{4}$-induced elevated levels of the above indices. Similarly, GO significantly prevented the decline in total proteins and the increase in triglycerides and total cholesterol resulted after $\mathrm{EOH}+\mathrm{CCl}_{4}$ administration in rat liver homogenates. In addition, $\mathrm{GO}$ pretreatment restored liver GSH levels decreased due to $\mathrm{EOH}+\mathrm{CCl}_{4}$ administration. The elevation in liver TBARS level due to $\mathrm{EOH}+\mathrm{CCl}_{4}$ administration was also prevented by pretreatment with both low and high doses of GO. Histopathological examination indicated that GO exhibited an obvious preventive effect against the centrilobular necrosis and nodule formation induced by $\mathrm{EOH}+\mathrm{CCl}_{4}$ administration. In conclusion, $\mathrm{GO}$ exerts hepatoprotective actions against $\mathrm{EOH}+\mathrm{CCl}_{4}$-induced toxicity in rats.
\end{abstract}

Key Words: garlic oil, alcohol, carbon tetrachloride, hepatotoxicity, rats

\section{Introduction}

Liver diseases remain one of the serious health problems. The high prevalence of bilharziasis and viral hepatitis in Egypt resides behind the wide occurrence of liver disorders especially hepatic fibrosis and cirrhosis (el-Zayadi et al., 1992). Liver injury caused by toxic chemicals and certain drugs has been recognized as a toxicological problem. In the absence of reliable liver protective drugs in medical practices, herbs play a role in the management of various liver disorders. A number of plants have been documented to exhibit hepatoprotective properties (Handa et al., 1986; Mehandale, 1990).

For thousands of years, garlic extracts have been used to treat infectious diseases. Contents of garlic oil, particularly E-ajoene, have shown a broad activity against several DNA and RNA viruses (Sheen et al., 1999). GO has been reported to reduce serum cholesterol and triglycerides' levels (Fenwick and Hanley 1985). GO contains other organosulfur compounds including diallyl disulfide. These compounds are 
known as hepatoprotective agents (Sheen $e t$ al., 1999). Also, organosulfur compounds suppress inducible levels of cytochrome P450 2E1; which is responsible for the bioactivation of a wide variety of hepatotoxins and for generation of deleterious oxyradicals (Kwak et al., 1995). In addition, organosulfur compounds enhance phase II enzymes such as glutathione S-transferases, UDP-glucuronyl transferase and microsomal epoxide hydrolase activities, which are essential for hepatic detoxification processes (Siess et al., 1997) Furthermore, organosulfur compounds in garlic oil enhance the activity of glutathione peroxidase and superoxide dismutase; the well documented antioxidant enzymes (Banerjee et al., 2001). Therefore, the present work was designed to explore the potential protective effects of $\mathrm{GO}$ against $\mathrm{EOH}+\mathrm{CCl}_{4}$-induced hepatotoxicity in rats. For that purpose the activity/level of AST, ALT, $\gamma$-GT, ALP, and bilirubin were assessed in rat sera. Moreover, the level of total proteins, triglycrides, total cholesterol, GSH and TBRAS were estimated in liver tissues. Furthermore, histopathological studies of rat liver sections were performed. The effects of $\mathrm{GO}$ against $\mathrm{EOH}+\mathrm{CCl}_{4}$-induced hepatotoxicity were also compared with that of silymarin; a known hepatoprotective agent whose efficacy is clinically established in alcoholic liver disease (Wellington and Jarvis, 2001).

\section{Materials and Methods Chemicals}

GO was purchased from Handa Fine Chemicals, Nottingham, UK. GSH, 5, $\grave{5}-$ dithio-bis-(2-nitrobenozoic acid), thiobarbituric acid (TBA), 1,1,3,3-tetraethoxypropane, and trichloroacetic acid were all obtained from Sigma Chemical Co. (St. Louis, MO, USA). Silymarin was purchased from Ranbaxy, Delhi, India. All other chemicals were of the highest available commercial grade.

\section{Animals and Animal Treatment}

Forty male Sprague-Dawley rats, weighing 200-240 g, were obtained from our animal facility (Ain Shams University, Cairo, Egypt). They were divided into 5 groups, each group consisting of 8 rats and kept under standard laboratory conditions. They had free access to a commercial pellet diet and water ad libitum. The room temperature was maintained at $25 \pm 2^{\circ} \mathrm{C}$.

The dose and duration of $\mathrm{EOH}$ administration in combination with $\mathrm{CCl}_{4}$ were standardized in a preliminary experiment. Accordingly rats were orally administered $2 \mathrm{ml} / 100 \mathrm{~g}$ body weight of $40 \%$ ethanol (v/v); daily for 21 consecutive days. On day 20, animals were injected subcutaneously with $0.1 \mathrm{ml}$ of $\mathrm{CCl}_{4}$ in olive oil (1:1) per $\mathrm{kg}$ body weight and were sacrificed $48 \mathrm{~h}$ later. Group I represented control vehicle-treated rats. In group II, rats were given $40 \%$ ethanol daily for 21 days, and on day 20 they were injected with $\mathrm{CCl}_{4}$. Animals of group III, IV and V were put to similar protocol as those of Group II. In addition they received a predetermined dose of GO (dissolved in corn oil) equivalent to 5 or $10 \mathrm{mg} / \mathrm{kg} /$ day p.o. or silymarin $(25$ $\mathrm{mg} / \mathrm{kg} /$ day p.o.) daily from day 15 onward till day 21 (Karunakar et al., 1997). The doses of GO were based on changing the recommended human daily dose into rat doses using Paget and Barnes tables (1964).

\section{Preparation of Samples for Biochemical Studies:}

Rats were anesthetized with ether; blood was collected by intracardiac puncture and livers were collected. Then, all animals were sacrificed. Blood samples were kept for $30 \mathrm{~min}$ without disturbing. The samples were centrifuged for 15-20 minutes at $2000 \mathrm{rpm}$ to separate sera.

\section{Biochemical Study}

ALT and AST were determined by the method of Reitman and Frankel (1957). Serum bilirubin was estimated as described by Dangerfield and Finlayson (1953). Also, sera were used to asses ALP and $\gamma$-GT activity following the methods of Kind and King (1954) and Tate and Meister (1985) respectively.

Liver homogenates were used to determine the level of triglycerides and total cholesterol (Fletcher, 1968; Allain et al., 1974). GSH was determined in liver homogenates following the method of Ellman (1959). Concentration of TBARS was measured in liver using the modified 
method of Ohkawa et al. (1979). The concentration of TBARS was expressed as nmoles of malondialdehyde per $\mathrm{mg}$ of protein using 1,1,3,3- tetraethoxypropane as the standard. Total protein in the tissue homogenates was also estimated (Lowry et al., 1951).

\section{Histopathological Studies}

Two rats from each group were sacrificed under light ether anesthesia and the liver samples of all groups were preserved in $10 \%$ neutral buffered formalin as described by Luna (1968). Thin sections were stained by hematoxylin and eosin stain. Representative sections were photographed under light microscope.

\section{Statistical Analysis}

Results are reported as mean \pm standard error of the mean (SEM). Statistical analysis was performed using one-way analysis of variance (ANOVA). If the overall F-value was found statistically significant $(p<0.05)$, further comparisons among groups were made according to post-Hoc Tukey's test. All statistical analyses were performed using SPSS statistical software package (SPSS $^{\circledR}$ Inc., USA), version 8. Graphs were sketched using GraphPad Prism (ISI ${ }^{\circledR}$ software, USA) version 2 .

\section{Results}

Results demonstrated significant increase in the activity/level of serum AST, ALT, $\gamma$-GT, ALP and bilirubin associated with marked depletion in the content of total liver proteins after $\mathrm{EOH}+\mathrm{CCl}_{4}$ administration (Table 1, Fig. 1A). Treatment with the two doses of GO resulted in restoration of serum and liver parameters disturbed after $\mathrm{EOH}+\mathrm{CCl}_{4}$ administration. The lower dose of $\mathrm{GO}$ resulted in $21 \%, 36 \%, 52 \%, 23 \%$, and $21 \%$ reduction in elevated activities/level of AST, ALT, $\gamma$-GT, ALT, and bilirubin respectively. The higher dose of GO decreased the increased activities/level of AST, ALT, $\gamma$-GT, ALP, and bilirubin by $30 \%, 56 \%, \quad 72 \%, \quad 33 \%$, and $43 \%$ respectively. Results also showed that silymarin caused $41 \%, 49 \%, 77 \%, 31 \%$, and $43 \%$ reduction in the elevated activities/level of AST, ALT, $\gamma$-GT, ALP, and bilirubin respectively (Table I). All treatment conditions significantly increased $(\mathrm{P}<0.05)$ the depleted content of total liver proteins caused by $\mathrm{EOH}+\mathrm{CCl}_{4}$ administration ( Fig A).

Table (I): Effects of GO on activity/level of AST, ALT, $\gamma$-GT, ALP, and bilirubin in sera of rats given combined administration of $\mathrm{EOH}+\mathrm{CCl}_{4}$

\begin{tabular}{|c|c|c|c|c|c|}
\hline Parameters & $\begin{array}{l}\text { Group I } \\
\text { Control }\end{array}$ & $\begin{array}{c}\text { Group II } \\
\mathrm{EOH}+\mathrm{CCl}_{4}\end{array}$ & $\begin{array}{c}\text { Group III } \\
5 \text { mg GO/Kg } \\
\text { /day } \\
+\mathrm{EOH}+\mathrm{CCl}_{4}\end{array}$ & $\begin{array}{c}\text { Group IV } \\
10 \mathrm{mg} \mathrm{GO} / \mathrm{Kg} \\
\text { /day } \\
+\mathrm{EOH}+\mathrm{CCl}_{4}\end{array}$ & $\begin{array}{c}\text { Group V } \\
25 \mathrm{mg} / \mathrm{Kg} \\
\text { Silymarin/day } \\
+\mathrm{EOH}^{\mathrm{EOH}}+ \\
\mathrm{CCl}_{4} \\
\end{array}$ \\
\hline AST (IU/L serum) & $20.30 \pm 0.41$ & $39.60 \pm 1.40^{\mathrm{a}}$ & $31.10 \pm 1.70^{\mathbf{a}, \mathbf{b}}$ & $27.50 \pm 1.2^{\mathbf{a}, \mathbf{b}}$ & $23.30 \pm 1.20^{\mathbf{b}}$ \\
\hline ALT (IU/L serum) & $22.10 \pm 0.62$ & $77.90 \pm 4.60^{\mathrm{a}}$ & $49.50 \pm 3.60^{\mathbf{a , b}}$ & $33.80 \pm 2.1^{\text {a,b }}$ & $39.60 \pm 1.50^{\mathbf{a , b}}$ \\
\hline$\gamma$-GT (IU/L serum) & $3.62 \pm 0.04$ & $21.60 \pm 1.10^{\mathrm{a}}$ & $10.30 \pm 1.21^{\mathbf{a}, \mathbf{b}}$ & $5.90 \pm 0.40^{\mathbf{a}, \mathbf{b}}$ & $4.80 \pm 0.13^{\mathrm{a}, \mathrm{b}}$ \\
\hline ALP (IU/L serum) & $74.20 \pm 5.20$ & $135.30 \pm 7.10^{\mathrm{a}}$ & $103.20 \pm 5.60^{\mathrm{a}, \mathrm{b}}$ & $89.80 \pm 4.7^{\mathbf{a}, \mathbf{b}}$ & $93.20 \pm 5.30^{\mathbf{a}, \mathbf{b}}$ \\
\hline Bilirubin (mg/dl) & $0.24 \pm 0.01$ & $0.71 \pm 0.02^{\mathrm{a}}$ & $0.56 \pm 0.02^{\mathbf{a}, \mathbf{b}}$ & $0.40 \pm 0.02^{\mathbf{a}, \mathbf{b}}$ & $0.40 \pm 0.01^{\mathbf{a}, \mathbf{b}}$ \\
\hline
\end{tabular}

Data are presented as mean \pm SEM.

${ }^{a}$ Significantly different from corresponding control at $\mathrm{P}<0.05$.

${ }^{\mathrm{b}}$ Significantly different from corresponding $\mathrm{EOH}+\mathrm{CCl}_{4}$ treated group at $\mathrm{P}<0.05$. 
In group II, a significant increase $(\mathrm{p}<$ 0.05 ) in the levels of triglycerides, and cholesterol in liver tissues was observed as compared to normal animals (Fig. 1B, 1C; respectively). Treatment with $\mathrm{GO}$ alone at both lower and higher doses (Groups III and IV) and silymarin (Group V) gave different degrees of protection against $\mathrm{EOH}$ $+\mathrm{CCl}_{4}$-induced hypertriglyceridemia $(21 \%$, $25 \%$ and $24 \%$ respectively) and hypercholestrolemia $(25 \%, 30 \%$ and $27 \%$ respectively).
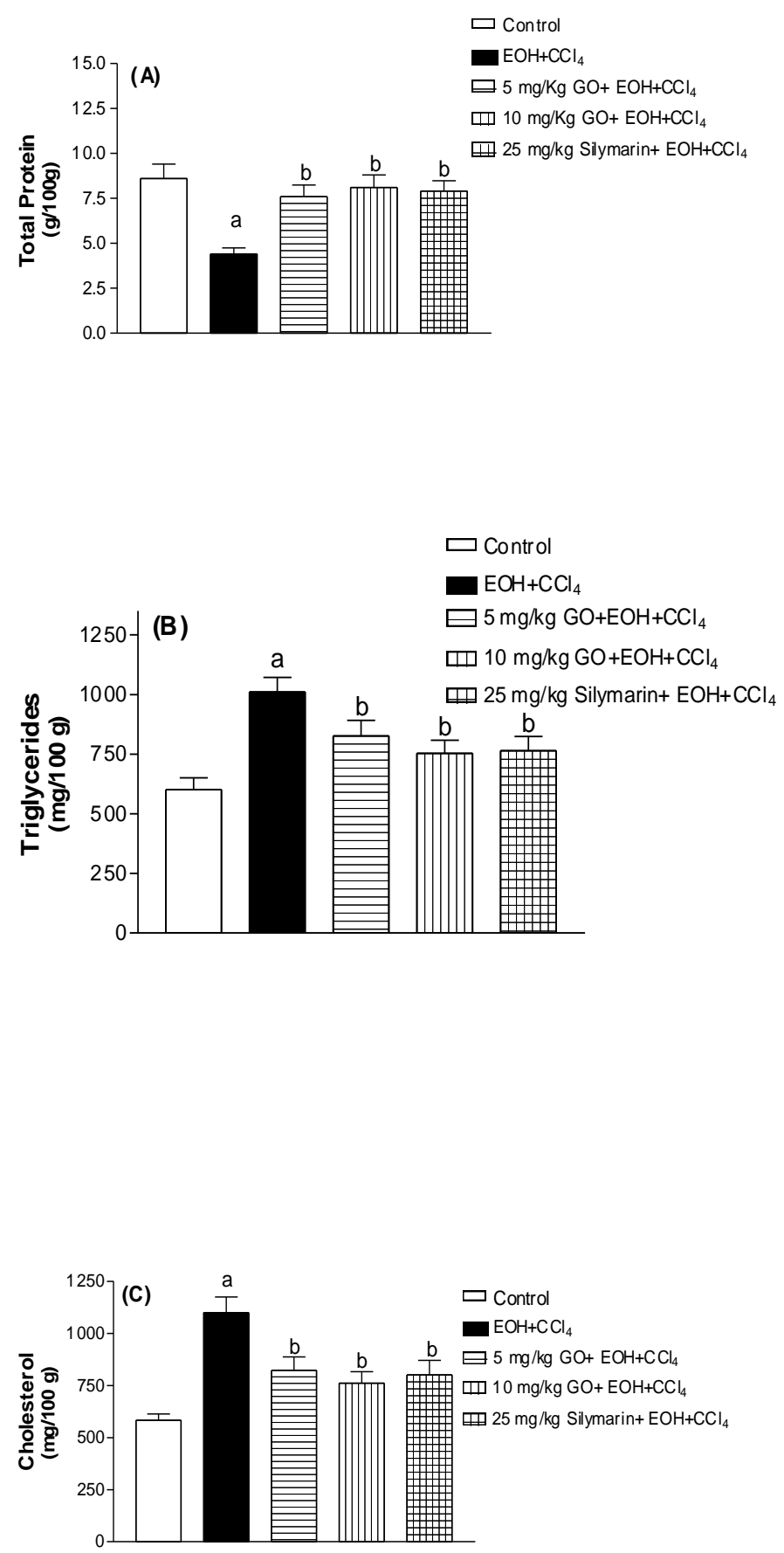

Fig.1: Effects of GO treatment on the level of liver total proteins (A), triglycerides (B) and cholesterol $(\mathrm{C})$ in rats treated with $\mathrm{EOH}+\mathrm{CCl}_{4}$

${ }^{a}$ Significantly different from control at $\mathrm{P}<0.05$.

${ }^{\mathrm{b}}$ Significantly different from $\mathrm{EOH}+\mathrm{CCl}_{4}$ treated group at $\mathrm{P}<0.05$. 
Tissue GSH level was significantly decreased in animals treated with $\mathrm{EOH}+$ $\mathrm{CCl}_{4}$ as compared to normal animals (52\%). The decreased level of liver GSH due to $\mathrm{EOH}+\mathrm{CCl}_{4}$ administration was significantly ameliorated by pretreatment of rats with both the lower and higher doses of GO and with silymarin $(40 \%, 60 \%$, and $61 \%$ of $\mathrm{EOH}+\mathrm{CCl}_{4}$-treated group respectively, Fig. 2A).
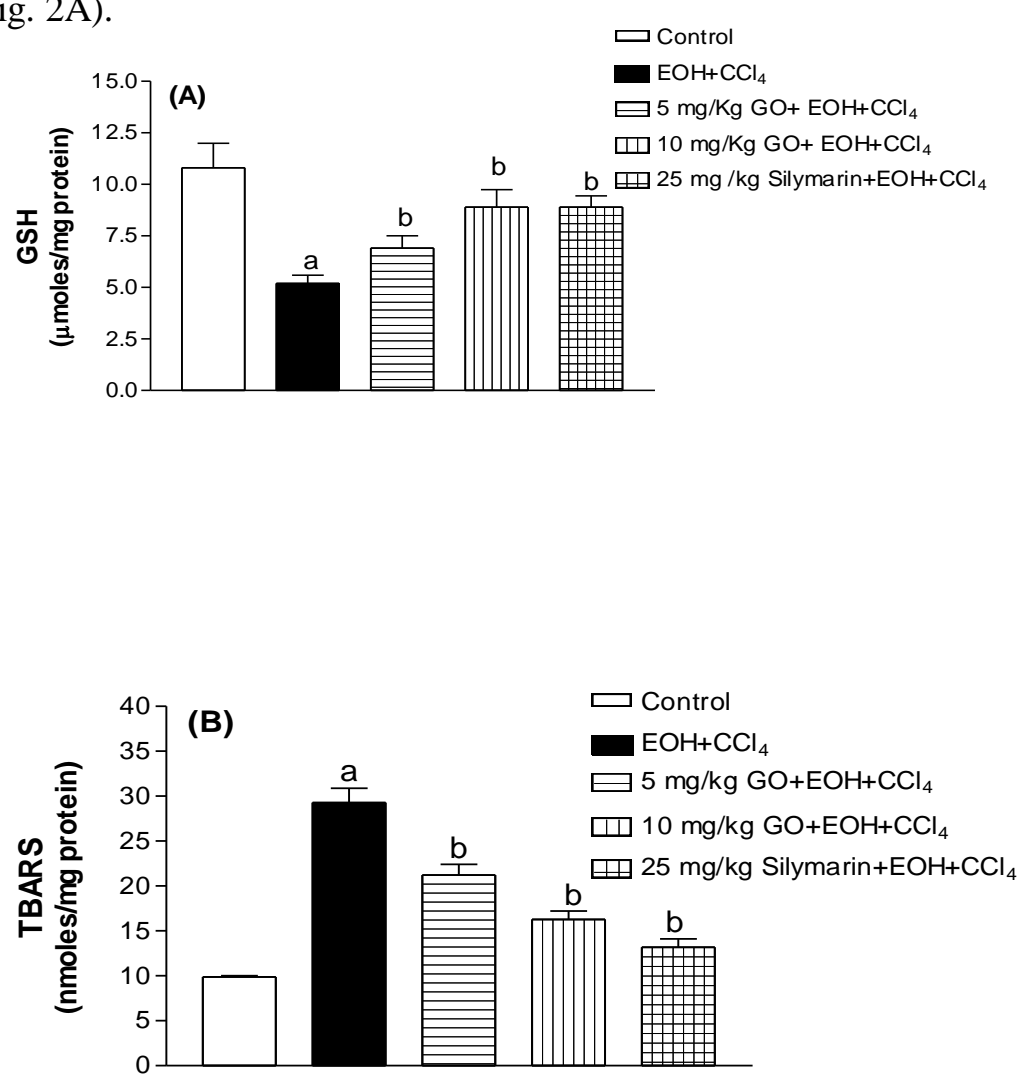

Fig.2: Effects of GO treatment on liver GSH level (A) and lipid peroxidation (B) in rats given combined administration of $\mathrm{EOH}+\mathrm{CCl}_{4}$

${ }^{\text {a }}$ Significantly different from control at $\mathrm{P}<0.05$.

${ }^{\mathrm{b}}$ Significantly different from $\mathrm{EOH}+\mathrm{CCl}_{4}$ treated group at $\mathrm{P}<0.05$.

Histopathological examination of liver sections of normal rats showed normal hepatic cells with well-preserved cytoplasm, prominent nucleus and nucleolus and well brought-out central vein (Fig. 3A). Administration of $\mathrm{EOH}+\mathrm{CCl}_{4}$ induced centrilobular necrosis and various degenerative changes in hepatic cells surrounding central vein. Such degenerative changes were demonstrated as cloudy swelling, hydropic degeneration, necrosis
Combined administration of $\mathrm{EOH}+\mathrm{CCl}_{4}$ resulted in a significant increase in the levels of tissue lipid peroxidation marker; TBARS. Such increase in TBARS was inhibited by pretreatment of rats with both the lower and higher doses of GO and with silymarin $(27 \%, 45 \%$, and $52 \%$ of $\mathrm{EOH}+$ $\mathrm{CCl}_{4}$-treated group respectively, Fig. 2B). 

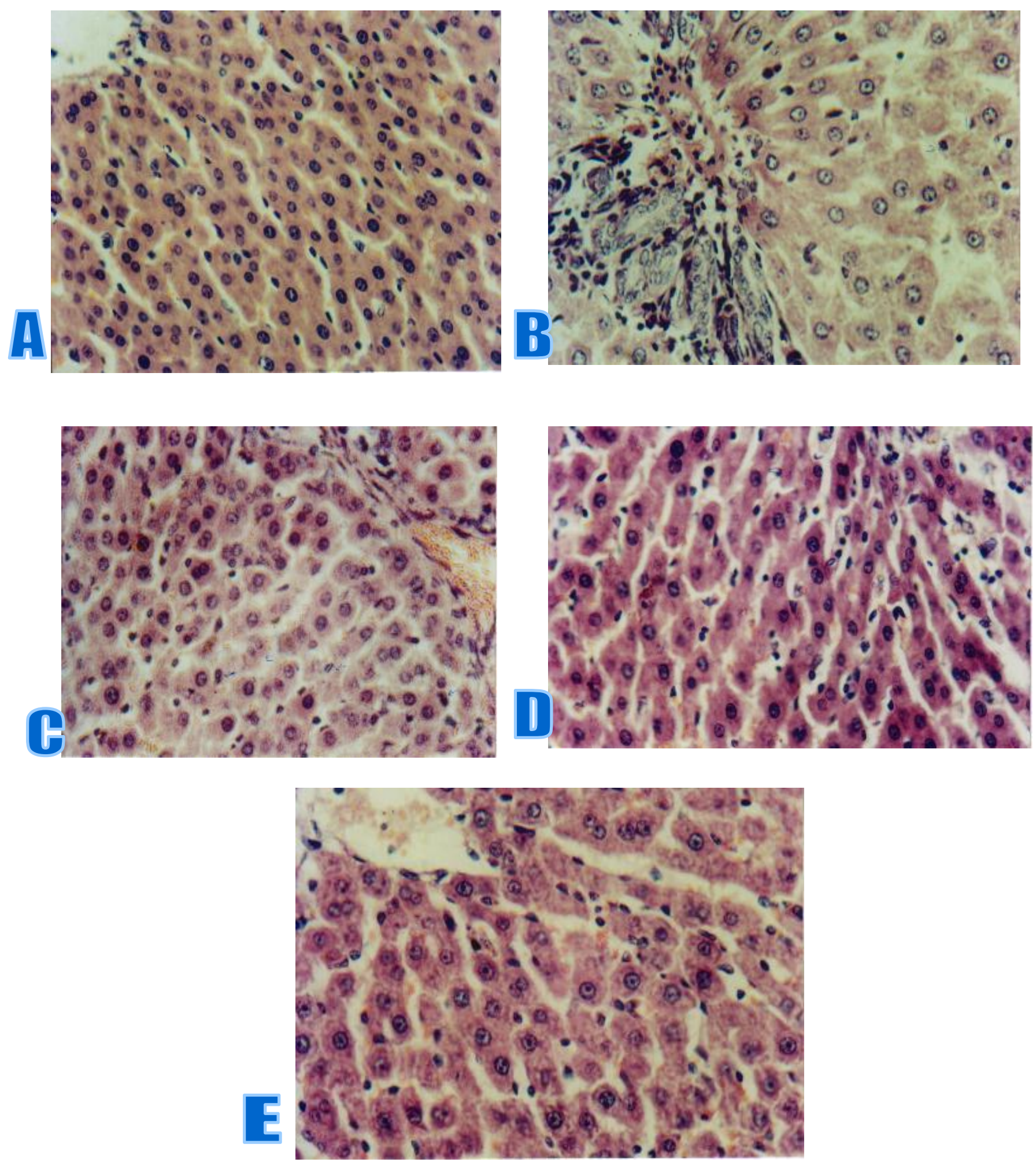

Fig. 3: Photomicrographs of rat liver sections in all studied groups

A: Liver of a control; B: Liver of a rat given combined administration of $\mathrm{EOH}+\mathrm{CCl}_{4}$; $\mathrm{C}$ and D: Liver of rats pretreated with 5 and $10 \mathrm{mg} / \mathrm{kg} \mathrm{GO}$ respectively $+\mathrm{EOH}+\mathrm{CCl}_{4}$; E: Liver of rats pretreated with $25 \mathrm{mg} / \mathrm{Kg}$ silymarin $+\mathrm{EOH}+\mathrm{CCl}_{4} ; \mathrm{X} 160$ 


\section{Discussion}

Hepatic dysfunction due to ingestion or inhalation of hepatotoxin is increasing worldwide (Loeper et al., 1983; Baraona et al., 1983; Ishak et al., 1991). The treatment of alcoholic liver disorder is a major problem. In the present investigation we have, therefore, evaluated the protective effect of GO in rat liver damaged due to combined administration of $\mathrm{EOH}+\mathrm{CCl}_{4}$. Such activity has been further compared with a known hepatoprotective agent; silymarin whose efficacy is clinically established in alcoholic liver disease (Wellington and Jarvis, 2001). Inclusion of $\mathrm{CCl}_{4}$, in this study was made to cause hepatocellular necrosis, as alcohol administration per se was not able to injure the liver beyond fatty infiltration in rats possibly because of a short life span.

Serum ALT, AST and ALP are reliable markers of liver function (Friedman et al., 1996). Indeed, they were significantly increased in $\mathrm{EOH}+\mathrm{CCl}_{4}$ treated group. On the other hand, in animals pretreated with GO (Groups III and IV), the increased activity of ALT, ALP and AST had decreased significantly. This suggests that the hepatoprotective action might be due to GO effects against cellular leakage and protection of the integrity of the cell membrane in rat liver. Similarly, the estimation of $\gamma$-GT levels is a valuable indicator for liver disease (Nemesanszky, 1996) as it is a membrane bound enzyme (Chander et al., 1994). A number of hepatotoxic drugs and chemicals are known to increase $\gamma$-GT activity (Kim et al., 1977). In the present study, the $\gamma$-GT activity was elevated in $\mathrm{EOH}+\mathrm{CCl}_{4}$-treated rats indicating a severe damage to hepatocytes' membrane. Oral administration of GO to $\mathrm{EOH}+\mathrm{CCl}_{4}$-treated rats showed reduction in $\gamma$-GT activity. This could reflect a possible membrane stabilizing activity of GO. In harmony with these results, GO significantly protected against the rise in serum bilirubin induced by the toxic chemical insult to rats.

The alcoholic liver injury appears to be generated by the effects of ethanol metabolism and the toxic effects of acetaldehyde, which may be mediated, by acetaldehyde altered proteins (Zimmerman, 1986; Ishak et al., 1991). Alcohol intake is known to produce hypercholesterolemia, hyperlipidemia and hypertriglyceridemia (Baraona and Lieber 1979). As a result of lipid accumulation, the liver cells become fibrotic leading to impaired liver function. Enhanced lipid peroxidation has been reported in hyperlipidemia which is also induced by ethanol (Loeper et al., 1983). Ethanol increases triglycerides and cholesterol levels thus inducing imbalance in lipid metabolism in liver and this could explain the reason for the increase in lipid peroxidation in these organs. In our study, assessing liver levels of tissue total proteins, triglycerides and cholesterol in liver tissues confirmed the deleterious effects of $\mathrm{EOH}+\mathrm{CCl}_{4}$ on these indices. However, GO treatment (especially in the high dose) was effective in preventing alterations in the above mentioned indices. It is worth mentioning that the effect of GO was comparable to that of silymarin.

The GSH system is an important endogenous antioxidant that is found particularly in high concentration in the liver and is known to have key functions in cellular protective mechanisms. GSH becomes readily oxidized to GSSG while interacting with free radicals. Excessive production of free radicals results in oxidative stress, which leads to damage of macromolecules (Sinclair et al., 1990). Thus, reduced GSH is essential to maintain structural and functional integrity of the cell. Human data strongly indicate a correlation between liver diseases and compromised oxidative status. Subnormal plasma concentrations of GSH were observed in cirrhotic patients (Chawla et al., 1984; Shigesawa et al., 1992). A fourto eight-fold decrease in plasma GSH was observed in cirrhotic patients (Loguercio et al., 1992). A significant decrease in cysteine in severe cirrhosis was also observed. Altomare and collaborators (1988) reported that GSH levels decrease in alcoholic and non-alcoholic liver diseases. In the present study, the observed decrease 
in liver $\mathrm{GSH}$ in $\mathrm{EOH}+\mathrm{CCl}_{4}$-treated rats may be due to non-enzymatic interaction of GSH with excessive free radicals generated by the toxic insult in rat liver (Knecht et al., 1995). Alternatively, it may be due to enhanced substrate utilization by glutathione peroxidase (Hiraishi et al., 1999). In general, the demonstrated protective antioxidant properties of GO can be attributed to its content of the organosulfur compounds (Fenwick and Hanley, 1985). These ingredients have been shown to possess antioxidant activity and to protect against experimentally induced liver damage (Wu et al., 2001). In fact, there is a direct correlation between GSH depletion and enhanced lipid peroxidation (Lieber, 1997). This was also observed in our study, as depletion of liver GSH was accompanied by significant elevation in liver TBARS. Our findings also revealed a significant reduction in liver TBARS level in the GOtreated groups (Groups III and IV). It is therefore concluded that GO could have obvious antiradical effects.

The histopathological findings demonstrated that combined administration of $\mathrm{EOH}+\mathrm{CCl}_{4}$ induced centrilobular necrosis and various degenerative changes in hepatic cells surrounding central vein. Treatment with GO as well as silymarin could obviously mitigate the histopathological changes. In conclusion, the results of the present investigation suggest that GO possesses a remarkable hepatoprotective activity against $\mathrm{EOH}+\mathrm{CCl}_{4^{-}}$ induced toxic insult.

\section{Acknowledgement}

The authors acknowledge Prof. Dr. Adel Bakeer Kholoussy, Department of Pathology, Faculty of Veterinary Medicine, Cairo University; for performing the histopathological studies.

\section{References}

1. Allain CC, Poon LS, Chen CSG, Richmond W, Fu PC (1974). Enzymatic determination of total serum cholesterol. Clin Chem 20: 470-475.

2. Altomare E, Vendemiale G, Albano O (1988). Hepatic glutathione content in patients with alcoholic and non alcoholic liver diseases. Life Sci 143: 991-998.

3. Banerjee SK, Maulik M, Manchanda SC, Dinda AK, Das TK, Maulik SK (2001). Garlic-induced alteration in rat liver and kidney morphology and associated changes in endogenous antioxidant status. Food Chem Toxicol 39: 793-797.

4. Baraona E, Lieber CS (1979). Effects of ethanol on lipid metabolism. J Lipid Res 20: 289-315.

5. Baraona E, Sanolainen M, Karrenty C, Leo Maria A, Lieber CS (1983). Pathogenesis of alcoholic hypertriglyceridemia and hypercholesterolemia. Trans Assoc Am Physicians 96: 306-315.

6. Chander R, Kapoor NK, Dhawan BN (1994). Picroliv affects $\delta$-glutamyl cycle in liver and brain of Mastomys Natalensis infected with Plasmodium burghei. Ind J Exp Biol 32: 324-327.

7. Chawla RK, Lewis FW, Kutner MH (1984). Plasma cysteine, cystine, and glutathione in cirrhosis. Gastroenterology 87: 770-776.

8. Dangerfield WG, Finlayson R (1953). Estimation of bilirubin in serum. $\mathbf{J}$ Clin Pathol 6: 173-177.

9. Ellman GL (1959). Tissue sulfhydryl groups. Arch Biochem Biophys 82: 70-77.

10. el-Zayadi A, Selim O, Rafik M, elHaddad $S$ (1992). Prevalence of hepatitis $\mathrm{C}$ virus among non $\mathrm{A}$ non $\mathrm{B}$ related chronic liver disease in Egypt. J Hepatol 14: 416417.

11. Fenwick GR, Hanley AB (1985). The genus Allium--Part 3. Crit Rev Food Sci Nutr 23: 1-73.

12. Fletcher MJ (1968). A colorimetric method for estimating serum triglycerides. Clin Chim Acta 22: 393-398.

13. Friedman LS, Martin P, Munoz SJ (1996). Liver function tests and the objective evaluation of the patients with liver disease. In. Zakim D. and Boyer T.D. (eds) Hepatology. A textbook of liver disease $3^{\text {rd }}$ WB Saunders; Philadelphia, London, Toronto 28: 791-810.

14. Handa SS, Sharma A, Chakraborti KK (1986). Natural products and plants as liver protecting drugs. Fitoterapia 57: 307-345.

15. Hiraishi H, Shimuda T, Ivey KH, Terano A (1999). Role of antioxidant defenses against ethanol-induced damage in cultured rat gastric epithelial cells. J Pharmacol Exp Ther 289: 103-109.

16. Ishak KG, Zimmerman HJ, Ray MB (1991). Alcoholic liver disease: pathologic, 
pathogenetic and clinical aspects. Alcohol Clin Exp Res 15: 45-66.

17. Karunakar N, Pillal KK, Hussain SZ, Rao M, Balani DK, Imran M (1997). Further studies on the antihepatotoxic activity of jigrine. Ind J Pharmacol 29: 222227.

18. Kim NK, Yasmineh WC, Frejar EF, Goldman AI, Theologides A (1977). Value of alkaline phosphatase, 5'nucleotidase, $\gamma$-glutamyl transferase and glutamate dehydrogenase activity measurements (single and combined) in serum in diagnosis of metastases to the liver. Clin Chem 23: 2034-2038.

19. Kind PRN, King EG (1954). Estimations of plasma phosphatases by determination of hydrolysed phenol with aminoantipyrine. J Clin Pathol 7: 322-326.

20. Knecht KT, Adachi Y, Bradford BU, Iimuro Y, Kadiiska M, Xuang QH, Thurman RG (1995). Free radical adducts in the bile of rats treated chronically with intragastric alcohol: inhibition by destruction of Kupffer cells. Mol Pharmacol 47: 1028-1034.

21. Kwak MK, Kim SG, Kim ND (1995). Effects of garlic oil on rat hepatic P4502E1 expression. Xenobiotica, 25: 1021-1029.

22. Lieber CS (1997). Role of oxidative stress and antioxidant therapy in alcoholic and non-alcoholic liver diseases. Adv Pharmacol 38: 601-628.

23. Loeper J, Goy J, Emerit J, Rozensztajn L, Jeny C, Bedu O (1983). Fatty acid and lipid peroxidation in human atherosclerosis. Sem Hop 59: 1657-1660.

24. Loguercio C, Delvecchio Blanco C, Coltorti M, Nardi G (1992). Alteration of erythrocyte glutathione, cysteine, and glutathione synthetase in alcoholic and nonalcoholic cirrhosis. Scand J Clin Lab Invest 52: 207-213.

25. Lowry OH, Rosebrough NJ, Forr AL, Ramdall RJ (1951). Protein measurement with the Folins phenol reagent. J Biol Chem 193: 265-275.

26. Luna LG (1968). Manual of histology, staining methods of Armed Forces Institute of Pathology. 3rd edition. New York. McGraw Hill, pp: 325-333.

27. Mehandale HM (1990). Potentiation of halomethane hepatotoxicity by chlordecone: A Hypothesis for the mechanism. Med Hypotheses 33: 289-292.
28. Nemesanszky E (1996). Enzyme test in hepatobiliary disease. In :Donald W Moss and Sidney B Rosarki, editors. Enzyme test in diagnosis. New York, Oxford University Press; pp: 25-59.

29. Ohkawa H, Ohishi N, Yagi K (1979). Assay for lipid peroxides in animals tissues by thioabarbituric acid reaction. Anal Biochem 95: 351-358.

30. Paget GE, Barnes JM (1964). Interspecies dosage conversion scheme in evaluation of results and quantitative application in different species. In: "Evaluation of drug activities: Pharmacometrics: Vol 1; Laurence DR and Bacharach AL (eds.); Academic Press London and New York; pp: 160-167.

31. Reitman, S, Frankel S (1957). In vitro determination of transaminase activity in serum. Am J Clin Path 28: 56-60.

32. Sheen LY, Chen HW, Kung YL, Liu CT, Lii CK (1999). Effects of garlic oil and its organosulfur compounds on the activities of hepatic drug-metabolizing and antioxidant enzymes in rats fed high-and low-fat diets. Nutr Cancer 35: 160-166.

33. Shigesawa T, Sato C, Marumo F (1992). Significance of plasma glutathione determination patients with alcoholic and non-alcoholic liver disease. J Gastroenterol Hepatol 7: 7-11.

34. Siess MH, Le Bon AM, Canivenc-Lavier MC, Suschetet M (1997). Modification of hepatic drug-metabolizing enzymes in rats treated with alkyl sulfides. Cancer Lett 120: 195-201.

35. Sinclair AJ, Barnett AH, Lunec J (1990). Free radicals and antioxidant systems in health and disease. Br J Hosp Med 43: 334344.

36. Tate SS, Meister A (1985). gamma Glutamyl transpeptidase from kidney. Method Enzymol 113: 400-419.

37. Wellington K, Jarvis B (2001). Silymarin: a review of its clinical properties in the management of hepatic disorders. Biodrugs 15: 465-489.

38. Wu CC, Sheen LY, Chen HW, Tsai SJ, Lii CK (2001). Effects of organosulfur compounds from garlic oil on the antioxidation system in rat liver and red blood cells. Food Chem Toxicol 39: 563569.

39. Zimmerman HJ (1986). Effects of alcohol on other hepatotoxins. Alcohol Clin Exp Res 10: 3-15. 


\section{التأثيرات الواقية لزيت الثوم ضد تلف الكبد المحدث بالإيثانول مع رابع كلوريد الكربون فى الجرذان التيدان}

أشرف بهى الدين عبد التعيم أ ـ أمانى إمام محمد خليفة ــ شريف حلمى أحمد ب

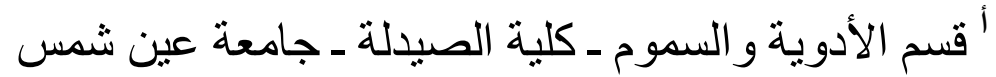

ب قسم الكيمياء الحيويه ـ كليـة الزر اعة ـ ـامعة جامعة القاهرة

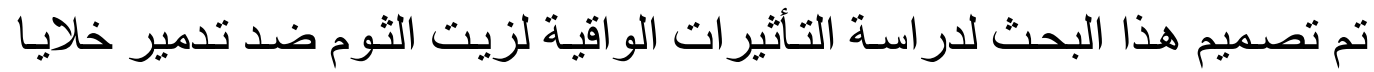

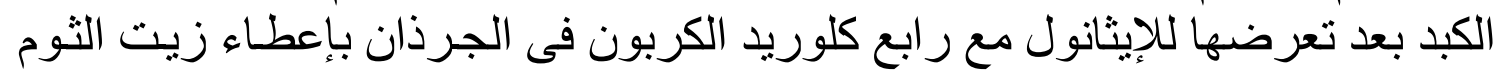

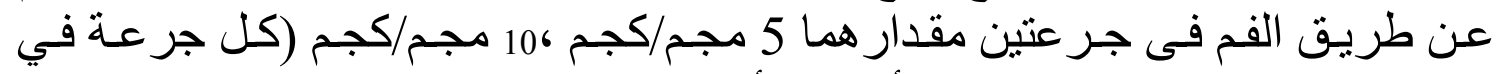

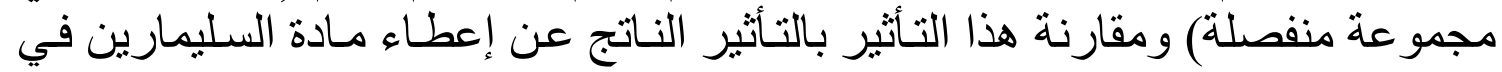

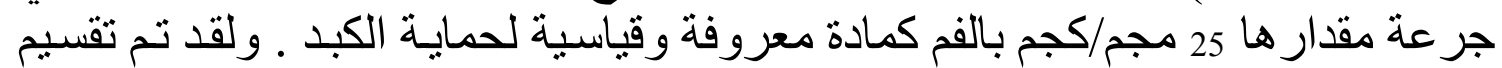

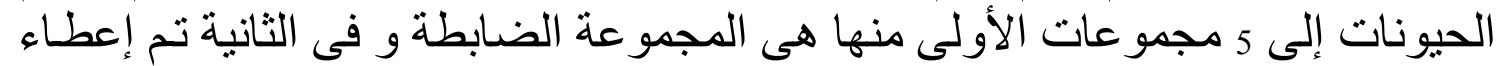

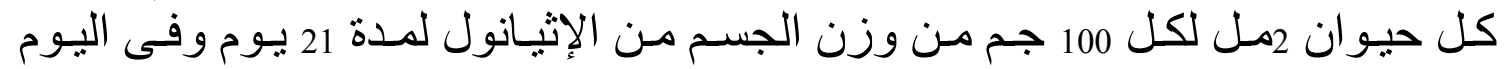

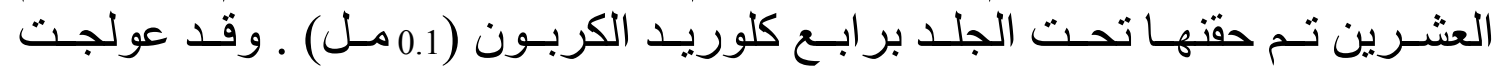

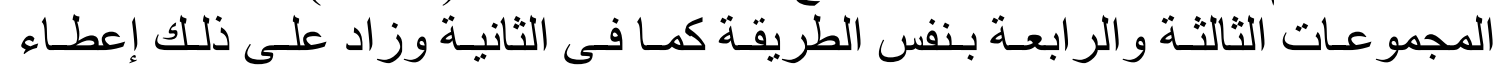

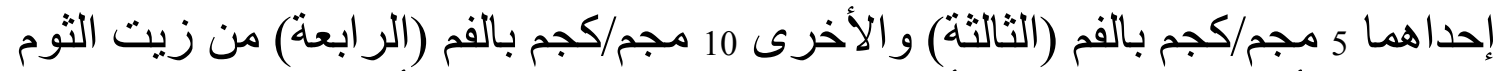

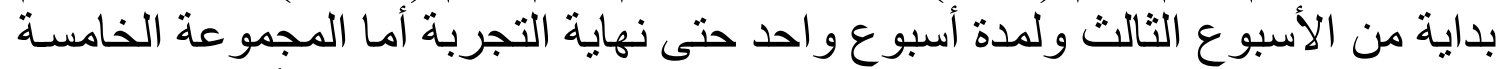

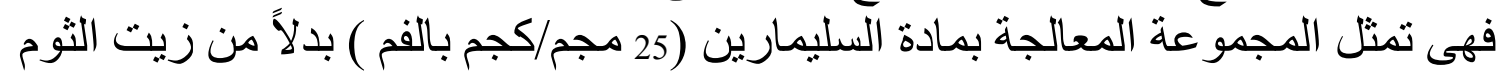

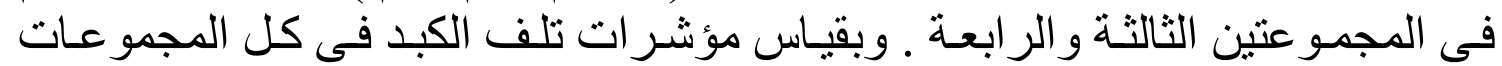

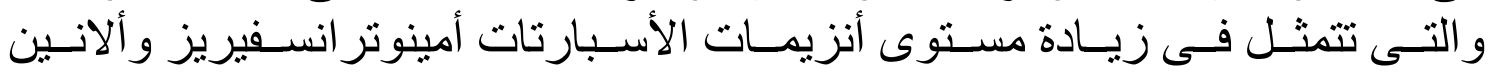

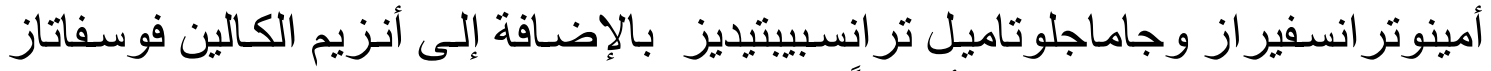

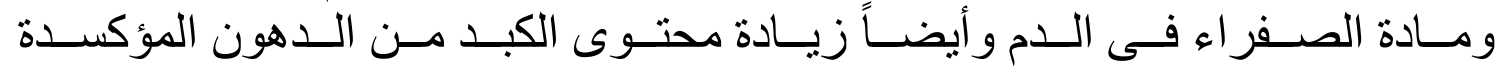

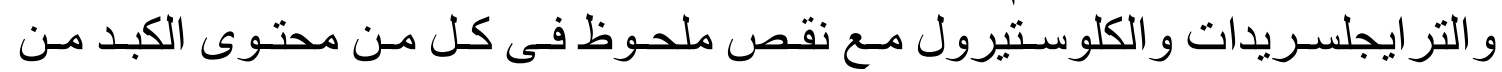

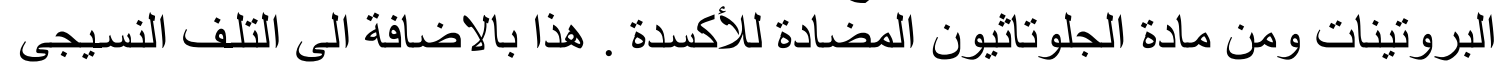

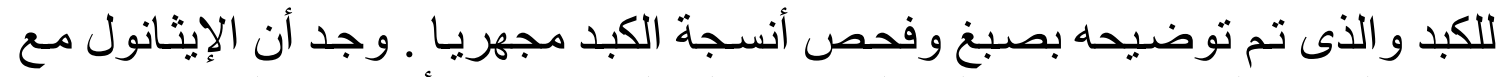

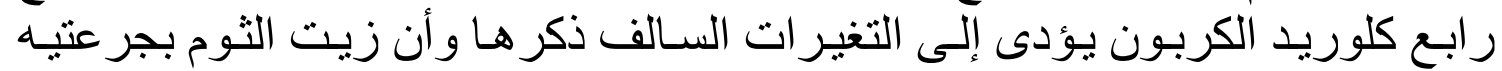

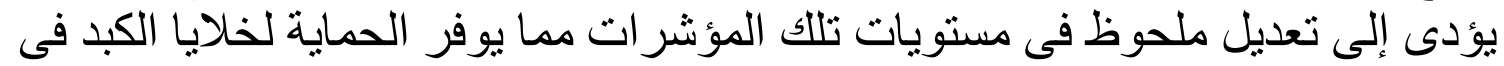

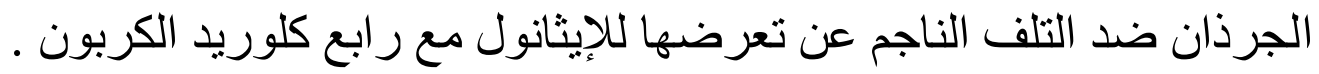

